\title{
Sociological Reflections on Governing Waste
}

\author{
G. HONOR FAGAN \\ National University of Ireland, Maynooth
}

ABSTRACT: The waste management issue in Ireland reached crisis proportions in the late 1990s. Reflecting on an all-Ireland empirical study of waste, this article develops a broader governance perspective and takes up the challenge of contributing to the sociology of waste. It situates waste in a 'multiscalar' perspective, viewing waste as a result of a complex global, national, local, and individual set of processes. It examines the dynamics involved in creating the conditions for the regulation and management of waste. It develops the notion of the 'networked state', and its implications for the processes of waste governance in Ireland. Finally, it focuses on the contestation of the Southern government's waste management plans and concludes that this is a positive effect of networking in a rapidly globalising Ireland.

\section{Introduction}

In social theory, waste must be seen as something of a 'lost continent', certainly a long way behind production and consumption in terms of analysis and understanding. It is only recently that we have seen the beginnings of a sociology of waste (see O'Brien 1999b; Yearley 1995) or a political economy of waste (Murray 1999), although there is popular US literature on the archaeology and history of 'trash' or 'garbage' (see Rathje and Murphy 2001; Strasser 1999). O'Brien rightly argues that contemporary sociology as a discipline, even when dealing with production and consumption at the level of everyday life, rarely deals with, theorises or acknowledges waste:

It is as if, for the discipline of sociology in general, and for sociological theory in particular, nobody ever throws anything away or ever carries out the bin-bags for a 'waste management authority' to deal with. It is as if, when you go to a shop, restaurant, club or place of work, you work, consume or take your leisure without ever producing rubbish or detritus of any kind. Sociology treats 'waste' as if it were literally immaterial, as if it existed in a world apart from the one we inhabit in our daily, routine lives (O’Brien 1999b: 62). 
Thus, in the so-called 'sociology of everyday life', but even in the more specialised sociology of the environment, where one would expect to see a link made between global consumerism and global waste and wasting, there is very little theoretical or even empirical analysis to date. Two major recent works in this substantive area (Becker and Jahn 1999 and Spaargaren et al. 2000) fail to address waste at all. A sociology of waste, I would argue, is urgently needed as it is key to understanding the relationship between social change and environmental change, that is, if one thinks of the earth as having limited resources. It is certainly as necessary as, and complementary to, those sociologies of production and consumption that have been central to sociology as a modern discipline.

The Republic of Ireland, as with the UK, in the late 1990s found itself with little infrastructure or policy capable of dealing with the increasing complexity of 'wasting' (as we might call the process as a whole). Hence, a 'waste crisis' became visible as it became clear that the Republic was in no position to meet EU regulations on waste flows. Following a belated recognition of the growing waste problem by the environmental authorities (see Dempsey 1998), seven regional waste plans were developed across the Republic. The aim of the plans was to reduce the 90 per cent of waste going to traditional landfill and to increase recycling from 8 per cent to 35 per cent over a 15-year period (targets set to meet EU requirements). However, at the core of the new strategy was a set of six large incinerators in Dublin, the South-East, Galway, Limerick, the Midlands and the North-East. Community opposition galvanised against these incinerators on health and other grounds, and against the full cost of their waste disposal being borne by householders. The 'waste crisis' can therefore be best understood as a dual crisis: one of spiralling waste and 'wasting', with its concomitant environmental problems, and one of governance where waste has not/is not being consensually governed in the Republic of Ireland.

Having recently collaborated on an all-Ireland study of this crisis (see Fagan and O'Hearn et al. 2001), I now propose to reflect on the subject in a less policyoriented way. The research report set about examining waste from a social science perspective, focusing on its social construction and the issue of governance. It reports on interviews carried out with 'key players' whom we asked to analyse the social forces involved in the crisis. ${ }^{1}$ It concluded with various policy recommendations on the need to follow the 'waste hierarchy' and build a genuine partnership process for better governance.

Building on this research, this article proposes to tell a sociological story of waste as it is produced, managed and contested in the context of contemporary Ireland. To do this, it situates waste in a 'multiscalar' perspective (see Massey 1992; Marston 2000); with waste viewed as a global, national, local, and individual process. It then examines Ireland's networked-state's dynamics in introducing regulation and management of waste. In doing so we begin to build insights into the networked political processes of waste governance. Much of the 'waste crisis' was/is blamed on community action against incineration where it was/is 
perceived to 'block' the progress of government strategy. This article examines community action against incineration as 'glocal action' and concludes that the problematisation of the state's waste management strategy has not arisen from 'NIMBYism' (a local not in my back yard approach), but is a positive effect of networked governance in a fast globalising Ireland.

\section{Waste - a Multiscalar Perspective}

The globalisation of contemporary capitalism's logic of increasing production and increasing consumption creates a material by-product of waste and an environmental 'externality' of wasting. Strasser's U.S. social history of trash traces how mass consumer culture brought into being a 'throwaway culture' as opposed to the previous one grounded in re-use and a philosophy of 'waste not, want not' (1999: 18). However, the nature, as well as the volume of the waste we are throwing away has changed considerably, which we can see in the historically unprecedented contemporary patterns of waste flows.

Trade in toxic wastes occurs at the transnational level, with toxic wastes changing hands between the northern world and the southern world in profitable and usually environmentally hazardous ways (Greenpeace 1993). The emergence of any form of regulation is very new in that before the 1970s the free market criterion of 'produce what you want so long as you can make a profit', prevailed unquestioned. Prior to the early 1970s, most OECD countries did not even have an analytical or legal framework for distinguishing between different types of waste. In Foucauldian terms - without definition, without naming, without statistical information - its regulation was simply socially impossible. Toxic waste scandals such as the Love Canal incident in the USA and the BT Chemie scandals in Sweden brought about the definition of certain wastes as hazardous (Held et al. 1999: 407) and with this 'naming' came possibilities for its regulation. Governance moves were made at the international level to create a common global list of agreed hazardous wastes, and, interestingly, it has in fact been the regulation of these that has been a 'driving force' behind establishing profitability of the international trade in hazardous waste (Held et al. 1999: 408). Again, ironically it is this 'naming', the differentiation between wastes and the shift towards its regulation, that has established the profitability of waste streams other than toxic ones, thus creating a market for waste.

A recent Economic and Social Research Council sponsored study in the UK on globalisation and the environment sees environmental flows as particularly global:

This is particularly true for flows related to the environment: greenhouse gases, ozone threatening gases and toxic wastes move from more developed to less developed countries; raw materials and commodities, produced at huge environmental costs flow from less developed to more developed countries (Urry 1999).

In the 1980s, the ecological debate shifted from the national to the global terrain. The 'limits to growth' were the focus; production had to be 'sustainable' 
and consumption had to be cut back. The Chernobyl disaster of 1986 brought home in a dramatic way that ecology was a transnational issue. The Rio 'Earth Summit' of 1982 may have produced the international declaration but it was Chernobyl (and Seveso) that produced a real social understanding of the biosphere as a single integrated whole. Then, as Robin Murray, puts it: 'As environmental concerns came to the fore in the $1990 \mathrm{~s}$, all roads led to waste. From centuries of obscurity the waste industry found itself at the hub of environmental argument' (Murray 1999: 20). Ironically, as the wave of international liberal privatisation based economics was peaking, the governmental response to the environmental threat, and waste in particular, was to increase and strengthen environmental and waste regulations. Waste emerged from obscurity to threaten the symmetry of the dominant discourse of neo-liberalism.

Global governance deals particularly with hazardous and toxic wastes, but the regulation of waste is approached from many other spheres of governance as well. At a European level, the nation state members of the EU are now required to manage waste under specific European guidelines, which must be adhered to under pain of severe financial penalties. The current situation at European level is that wasting is posing serious regulatory problems and its flows are recognised as being well of out of control. The European Environmental Agency presents a disturbing scenario: 'The expected waste trends during the outlook period [up to 2005] suggest that existing policies, although providing some degree of success, will not be sufficient to stabilise waste arising, meet policy objectives, or progress towards sustainability' (European Environmental Agency 1999: 215).

Municipal waste, while only making up approximately 14 per cent of total waste (EEA 2002: 103), gets most public attention as it appears impossible to stabilise growth rates. While there are significant limitations to the data, municipal waste and construction/demolition waste streams are still increasing, averaging 540 kilograms per capita in 1999 (EEA 2002: 103). In the waste categories most familiar to the domestic consumer, such as paper, cardboard, glass and plastic, the proposed recycling efforts do not offer a sustainable solution. Many countries have increased recycling rates but, according to the EEA, this development 'has been only a partial success, because the total amount of waste paper and waste glass (container glass) generation has also increased in the same period' (EEA 1999: 3). The sheer quantity of waste in circulation is extraordinary: European statistics for 1999 show $2,000,000,000$ tonnes of waste being generated per year, with that amount increasing by 10 per cent each of the previous 6 years. The European Environmental Agency estimated that all waste streams would continue to increase steadily (EEA 1999:203). The overall aim of the European regulations on waste is to prevent waste being generated and a specific objective of the EU's sixth environmental action programme is to de-couple waste from economic growth. Where waste continues to be generated, the aim according to this action plan is (a) that the wastes be non-hazardous, (b) that most wastes be reintroduced into the economic cycle through recycling or returned to the environment in a harmless 
form through composting, (c) that the quantities of waste that still need to go to final disposal are reduced to an absolute minimum and are safely destroyed or disposed of and, finally, (d) that waste is treated as close as possible to where it is generated (EEA 2002:100).

That the nature, as well as the volume, of the waste we are generating has changed considerably can best be observed in a growth phase such as the one we have just encountered in the Republic of Ireland. The Republic of Ireland's successful insertion into the new phase of globalised capitalism (in sharp evidence in its 'Celtic Tiger' economic growth phase) creates, and is affected by, waste material by-product and its environmental consequences. As with all European states, the quantity of waste is increasing all the time in the Republic of Ireland, although there is an above average growth rate in its production. Between 1995 and 1998, waste flows in the South increased by a phenomenal 89 per cent (Forfás 2001:2). Industrial waste figures show encouraging increases in recovery, from 12 per cent in 1995 to 27 per cent in 1998, but this is outweighed by the significant increases in growth (EPA 2002: 26). The figures for 2000 indicate that household and commercial waste volumes rose by 60 per cent in the previous 5-year timeframe with an average of 600 kilograms of waste being generated per person per year (EPA 2002). This risky fluid currently goes to landfill sites (the most risky environmental option according to the waste management hierarchy adopted by the EU and Irish and UK governments) where it is 'grounded' (EPA 2002). A further 87.8 per cent of the household and commercial waste is 'disposed' of in this way (EPA, 2002). Only 12.2 per cent of waste was recycled in 2000 , against the set target of 35 per cent. However, the prevailing practice of landfill, while resulting in waste being grounded, of course, does not block its continuous circulation as environmentalist scientists and community residents beside landfill sites testify. Hazardous wastes are on the whole not dealt with in Ireland but, rather, are shipped out of the country to other European sites.

While we can see waste as a global fluid, with risk and profitability associated with its movement, at the same time we also need to conceptualise it as an extremely localised phenomenon. If we start at the local site of the individual and their waste bin, the statistics point to each person in the Republic of Ireland 'producing' more than the European average of one kilogram of municipal waste per day. The EPA (2002) estimates that every citizen of the state in the Republic is producing an average of 600 kilograms of waste a year, which is almost double the European average. In doing so we are actively engaged in a social process and social relations of 'wasting' through our pattern of consumption. In being 'interpolated' as consumers, we purchase what has been produced in the format in which it is produced. We have some choice, as some forms of consumption are environmentally better than others, but by and large consumerism is systematically organised along lines more concerned with profitability than with a sustainable environment. This may be changing and transformation is possible in that the individual could perhaps be 'interpolated' as an environmentally concerned 
consumer, and some or all markets could respond to this trend. This may occur, but the current situation is one where on average the contents of the waste bin are becoming greater, there are more of them, and there are things in them that are worse for the environment than ever before. While the individual consumer may not be producing the hair spray canister, the plastic tractor or the twenty-one socalled 'disposable' nappies (surely a misnomer for something that simply cannot be got rid of and takes longer to decompose than the old cloth nappies) they are playing a role in its wasting. In other words, the consumption pattern of the household result in the waste bin as we know it, albeit one that could be very different if the forces of production were regulated to produce commodities that were truly of less negative impact on the environment.

The organisation of the waste bin, once filled, is that it is 'put out', to be dealt with at regional and national level, where its malign geographic footprint becomes more visible on the Irish environment. While waste is a material outcome of globalised consumerism and 'development', who are the key players in its governance and how can we analyse it in terms of politics of scale? Who governs, regulates and strategises waste flows? In our study, of waste management strategy North and South (Fagan and O'Hearn et al. 2001), there was very little doubt on the part of all those interviewed as to who the key actors were and EU governance was clearly considered to be the key driver.

There is very little doubt that this is, indeed, the case. The European Union Act of 1972 gave 'direct effect' to European acts over domestic laws and constitutional provisions in the Republic and in Northern Ireland (NI). The ratification of the Single European Act (1986), the Treaty of Maastricht (1992) and the Treaty of Amsterdam (1997) further ensured the supremacy of EU law over domestic law. EU legislation includes Directives on dangerous substances, waste oils, groundwater, urban waste water, licensing regulations, the disposal of toxic waste, sewage sludge in agriculture, emissions from waste incineration plants, the disposal of animal waste, and batteries containing dangerous fluids. The extent of the national input is that at European level they inform the discussion given that the EU is a network made up of nation states. Then, when the Directives are in place, the nation states, in their own jurisdictions, have some leeway with the 'how and when' of implementation. While Directives do set out a stated time period for implementation, it is essentially up to individual Member States to decide how the individual Directive is to be given effect. Directives, therefore, are not directly or immediately applicable to domestic law. However, failure to implement a Directive within the given period of time can result in a Member State being penalised by the European Court of Justice. Early EU Directives were of particular relevance to the formation of Irish and UK government policies on waste management including Council Directive 75/442/EEC - July 1975, which states that Member States must encourage steps that prevent and minimise waste flows. These include recycling and the extraction of raw materials and energy for re-use of waste (Article 3). It also notes that Member States must ensure that waste is disposed of 'without endangering 
human health and without harming the environment, and in particular: - without risk to water, soil, and plants and animals, without causing a nuisance through noise or odours, without adversely affecting the countryside or places of special interest' (Article 4). Thus the 'green' quality of the regulations is firmly in place.

This Directive was later reinforced to ensure that the Community as a whole, and Member States individually, should aim towards self-sufficiency in waste disposal (Article 5, Council Directive 91/156/EEC (March 1991) amendment to Directive 75/442/EEC). Furthermore, the EU wanted the establishment of 'a competent authority' in order to plan, authorise and supervise waste disposal operations (Article 5). This plan was to include the type and quantity of waste, suitable disposal sites, costs, and 'appropriate measures to encourage rationalisation, of the collection, sorting and treatment of waste' (Article 6). The authority was also charged with issuing permits to those who store or tip waste on behalf of a third party (Article 8), and was to ensure that the conditions of the permit are fulfilled thereafter. As a sanction against default, waste costs would be in accordance with the "polluter pays' principle (Article 11).

So the EU is a key player in real terms and it is also perceived as the key player in regulating waste. The EU legislation impacts on the development of strategy at the national level (on the local implementation 'deficit' in Ireland see Quinlivan 2002). However, no scalar process is ever so simple - EU policy emerges from a network of actors and competing agendas. In the regulation of waste we can clearly see the agenda informed by sustainable environment concerns. This legislation clearly reflects networked green politics, but at the European level the contradiction between the concepts of development (market-driven in its capitalist form) and sustainability (the earth as limited resource) are regularly played out.

\section{Governing Waste in the Network State}

There is now a wide-ranging debate on the nature of the contemporary state, which is directly relevant to the analysis of the state's role in waste management strategy. For Philip Cerny we now have a 'competition state' driving globalisation and eroding the 'inside-outside' distinction of the classical nation state (Cemy 2000: 30). The state is transformed, but its much-vaunted death proclaimed in early globalisation studies has not occurred. Carnoy and Castells (2001) also show how far we have come from the classic 1970s statement of Marxist state theory by Nicos Poulantzas. They argue that the state can now best be described as a 'network state', just one player among others when it comes to state control of knowledge and information. Globalisation, time-space compression and the information society have created a new 'Network State' 'made of shared institutions, and enacted by bargaining and interactive iteration all along the chain of decision making' (Carnoy and Castells 2001:14) from the supranational to local government and NGOs. According to them decision-making and representation take place all along the chain, not necessarily in the hierarchical pre-scripted order. The new 
state 'functions as a network in which all nodes interact, and are equally necessary for the performance of the state's functions' (Carnoy and Castells 2001: 14).

Carnoy and Castells assert that all nodes are 'equally necessary' but the development of waste management strategy would suggest that some nodes are certainly 'more equal than others'. With the EU able to enforce sanctions on the nation state and the national governments needing to radically change the waste flows, the drawing up and implementing of strategy quickly becomes an issue of governance in the networked society. As Stoker puts it 'governance recognises the blurring of boundaries and responsibilities for tackling social and economic issues' (Stoker 1998: 21). Both in terms of strategic decision-making and of service delivery there is a widespread turn away from the 'Westminster model' of government to a more networked model of governance more in line with the complex networked societies we live in.

In terms of waste management strategy then, government by central decree would be a virtual impossibility. Governments thus attempt to move to a strategy based on a more consensual model based on multi-agency partnerships. Selfgoverning networks, in relation to waste management, would, from this perspective, be much favoured. The 'capacity to get things done' does not simply rest on the power of government to command and this will be done only in a last instance scenario. It rests on developing new mechanisms to steer and guide. Waste governance will not be resolved in terms of sustainability without widespread social and political consensus. For most governments, in order to reach the targets it is necessary to bring key players such as 'private enterprise' into some form of partnership. They can achieve this with a 'stick' if necessary, as they are the body responsible for regulating waste production, but in line with governance the preferred option would be to achieve this with a 'carrot' approach. The current Minister for the Environment, Mr. Cullen, consulting with businesses, looked for initiatives coming from the private sector to reduce waste going to landfill but declared 'Where initiatives are not forthcoming, I will not hesitate to regulate' (The Irish Times 9 October 2002).

The development of waste management strategy at the national level does point to the state as being networked. It is in fact the transnational politics of EU policy that has forced the nation state to carry out policies in this case. There was widespread consensus, across the spectrum of waste management 'actors' interviewed that it was the EU that demanded that Ireland should manage its landfills better, and seek an end to pollution (Fagan and O'Hearn et al. 2001: 42). It is also evident that the policy built at European level was fed into by the nation state, but also influenced by a transnational environmentalist movement. In our study, the environmentalists, the environmental scientists, and the environmentally minded politicians were all extremely happy with the EU Directives. According to one of the Southern environmentalists we interviewed, they were considered to contain an 'alternative worldview on sustainable development' which had come from the 'drive of civil society' NGOs concerned with environmental issues (Fagan and 
O'Hearn et al. 2001: 10). So it is clear that the contemporary state functions more like a node in a network, charged with implementing the Directives at national and local level, rather than as a centralised 'headquarters'.

Waste policy at EU level is partially driven by civil society in the form of the environmental movement, but policy implementation is often opposed at the local level by the same elements of civil society with many of the same environmental concerns that drove policy in the first place. The all-Ireland waste study points to the state acting to 'filter' out those elements of the EU policy that are more threatening to powerful interest groups. It concluded that state strategies such as 'individualisation' had been employed, where domestic householder's waste was being emphasised, over and above agricultural and industrial waste, and marketisation had been employed, where they try to make the final waste product 'profitable'. They were present in the discourse of all of the players in the waste management strategy, even in those most radical environmentalists who would wish to emphasise sustainability over profitability (Fagan and O'Hearn et al. 2001: 41-42). When it comes to the implementation of these Directives at national level, the tension played out is most certainly between questions of sustainability (which regions and localities seem to be pushing more than the state) and questions of profitability (spoken for by industry and increasingly spoken for by the state). The question of financing the infrastructure for dealing with waste at national level appears to be the most urgent side of the equation at national level in order to meet EU Directives on targets.

Observing the development of a waste management strategy in both parts of the island allowed us to look at the scope and power of the state in a period of globalisation, transnational and intergovernmental governance. In both NI and the Republic, European policy was seen to be the driver, and in both jurisdictions there were almost no regulations in place in advance of European intervention. In the Northern jurisdiction, according to an environmentalist interviewed, 'we are only off the starting block' (Fagan and O'Hearn et al. 2001: 10). According to an Environmental Protection Agency respondent in the South, the practicalities on the ground were:

We have done very little in the waste area through the 1970s and 1980s, and it wasn't until the 1990s that any kind of focus started on waste. And because we didn't start when we should have, we are twenty-five years behind others. (Fagan and O'Hearn et al. 2001: 13)

In other words, before the Irish states were networked into a European system they were simply not governing waste, they were 'disposing' of it in landfill sites.

The policy in the North and South differed in terms of how they approached the issue of participatory democracy, the necessity for good governance, and the development of political and social consensus on strategy. The Northern environmentalists were certainly happier with the form governance took in their jurisdiction, but perhaps they had an opportunity to learn from the mistakes made in the Republic as the North's waste plans were developed almost a year after those in the 
South. Consultation was widespread and environmentalists felt there had been full opportunity to have their point of view represented in the strategy (Fagan and O'Hearn et al. 2001: 16). On the other hand, the Southern environmentalists and local communities threatened by incineration plans were deeply critical of the 'façade' of consultation that had occurred. According to the Southem environmental scientist we interviewed, a large element of the plan was based on regional incinerators developed by a company of engineers for the government:

That goes out to the public for their 'consultation', back come all these comments.

The engineering firm, who have produced 90 per cent of the plans, defends the plan against comments, and we get nowhere. (Fagan and O'Hearn et al. 2001: 18)

As a result of this process, we see local communities, joined by environmentalists, environmental scientists, and environmentally-minded politicians, opposing plans in the Republic.

This amounted to what was referred to as a 'waste management crisis' in the South, where throughout 2000-01 local communities successfully blocked regional plans. This marked a high point in the power of the political action of locals embedded in a geographical community, backed by environmentalists; and marked a low point for the nation state's decision-making power. The state reaction was that the Minister at the time, Mr. Noel Dempsey, removed the local councillor from the decision-making process and replaced her/him with the county manager, a government employee. So, here, in response to challenge 'from below', a central decree - traditional statist government as opposed to governance of regional communities - was enacted to achieve the localising or embedding of waste management. This is not to say that the state moved entirely back to government by decree, or rejected consensus politics and involvement in multi-agency partnership, but, rather, that they removed the locality from involvement in the decision-making process. The new Minister, Martin Cullen, stated that the planning process on waste management was 'over-democratised' and that he did not believe it was 'adding anything to it by having so many layers involved' (The Irish Times 12 September 2002). So, the 'fast-tracking' of waste management plans was implemented, where An Bord Pleanála became a 'one-stop shop' for assessing all plans for new waste management faciiities. Objectors could now raise their objections at An Bord Pleanála hearings rather than at the local authority level. The Minister insisted he was not removing any groups' or individuals' rights to express their views: 'It's sacrosanct, but I don't see a need for these views to be expressed at so many different levels' (The Irish Times 12 September 2000). It would appear that the Minister had not fully accepted the implications of 'multi-scalar govemance'.

There is a need for an estimated investment of 1,000,000,000 euros over the next 3-5 years to implement the waste development plan (Forfás 2001: vi) and the National Development Plan envisages this coming from the private sector. Clearly, the Republic of Ireland faces a gruelling task to organise for targets set at a fivefold increase in recycling and to find the money for the infrastructure, but the plan 
is for the private sector to answer the call. Obviously, this sector then is a necessary 'node' in the governance of waste management, and of major significance to the outcome, not a dispensable partner like the local community.

\section{Waste and 'Glocal' Action}

Waste is a global fluid and therefore a global issue, but it is also clearly a local issue, so that we can legitimately use the fashionable term 'glocal' to frame its parameters. According to Dirlik: "'Glocal" expresses cogently what Latour has in mind by the hybridity of the global and the local. What it forces us to think about is a double process at work in shaping the world: the localization of the global, and the globalization of the local, neither, as Latour warns us, "to be confounded by the product"' (1999: 156). That is to say, waste is at one and the same time global and local, if we wish to characterise it in such terms. It is created in someone's locality and dumped or burned in another locality, yet it also flows around globally. The political economy of waste is thus embedded in multiple locales.

The issue of the global and the local is not a straightforward one. When it comes to analysing political action around waste management strategy from the point of view of networked political action, we can see a complicated dynamic in play. For some progressive (and not so progressive!) social or political movements, the global is, in and of itself, compared to an uncomplicatedly 'good' local level. The global is seen as the terrain of capital while the local is the terrain of the people. Yet, as Doreen Massey explains 'setting up the question as local versus global is to accede to spatial fetishism ... Imagining that space has a political meaning ... to assume that the local is always better ... This is to side-step the real problem' (Massey 2000: 8).

I argue that local action is in fact glocal action precisely where it is networked political action. Political networks, for me, are like the Gramscian concept of civil society in that they both enable and disable citizen participation and power. I read Castells in this vein when he argues that 'dominant activities in our societies are made of networks: Global financial markets ... science and technology ... the Internet as a universal, interactive communication network ... [But] I would also add that increasingly, counter domination operates through networks as well' (Castells 2000: 110). We may recall that, for Gramsci, civil society was the realm in which the social order was grounded ('state = political society + civil society') but also where a new order could be founded through a process of social transformation.

In terms of a sociology of 'wasting', there appears to be a particular multifaceted dynamic of actors, and there is a shifting importance of one over the other, which can be interpreted through the lens of a loose network analysis. The waste industry is clearly a global corporate network of considerable power and dynamism. The neo-liberal privatisation wave of the 1990s has led to the heightened interest of corporations in waste. The modern waste management methods require massive 
investment with a typical 420,000 tonne incinerator now requiring an investment of 200,000,000 euro (Murray 1999: 20). This means that the industry is typically dominated by a handful of big transnational companies. The Meath incinerator required an investment of $85,000,000$ euros and the Indaver corporation, with its subsidiary company Indaver Ireland, was obviously in a position to make this type of investment and is seeking to make further investments. Global corporate networks are clearly then part of the waste management scene. The state is also part of a state network through the European Union. Political parties and campaigners, active in the waste and environmental issues, are also part of networks. But the question remains, do they all have equal capacities to be agents of social change?

Local communities, without question, are important players in the above dynamic, but there are ebbs and flows in their political power. When waste first hit the scene as an issue in the Republic it was on the basis of local concerns around landfills in the early 1980s. This was an uphill struggle and the local concerns got very slow acknowledgment from the state. The EU Directives resolved the conflict over 'waste disposal', between communities and local and government authorities (not the national government). Where previously you could open a landfill site just by obtaining permission from the county council itself, now they had to be licensed by an Agency established to meet European Directives. So local communities opposition to landfill was being strengthened because of the EU legislation and the 'Green' argument was being strengthened and built on at local community level. However, with the waste management strategy in the South, the environmental activists and scientists felt that the government turned to incineration on the advice of one single engineering company and 'incineration was put into all the regional plans' but 'not up front' (Fagan and O'Hearn et al. 2001: 12). One can see that incineration is the contested terrain in this case, as not one government policy or regional plan mentions the word 'incineration'. The word used repeatedly and pointedly is 'thermal treatment plant'. As in all conflicts, the discourse itself marks the terrain and the use of the word 'incineration' as opposed to 'thermal treatment plants' normally marks the political division. A useful research project would be a semiological analysis of the terminology chosen in media reporting over the past three years. By simply looking at which descriptor is chosen one could tell which representations of the conflict are being heard and the political status of the "local campaigners" complaints at any one time.

Of crucial importance is the extent to which action taken around incineration and waste management can be conceived as being 'glocal', that is at once fiercely local but also networked to global community action. The Internet was used from the very start to gain access to technical information and to build support from other similar groups. From as far away as Australia and from as close as Northerm Ireland, expertise, technical and campaign-wise, flowed into one particular campaign group we observed closely. There seems little doubt that the participants' view of the world was transformed by this experience, and while the campaign was embedded in a locale it was clearly networked into the global environmental movement. 
With the new political process in place to bypass local councillors, the state's first incinerator got the go ahead from An Bord Pleanála in March 2003. This permission was granted despite a petition signed by 26,000 people and 4,500 individual objections lodged against the planning application. In addition to this it had been made known to An Bord Pleanála that the company involved, Indaver, had been forced to close down one of its facilities in Antwerp twice in the six months previous to the decision. So a remarkable amount of networking had gone into the campaign against the Meath incinerator. On receipt of the decision the campaigners immediately stated to the newspapers that they would be going to Europe to lodge their objections there: 'This may still end up before the European courts because of the failure to consider health and environmental matters, and, as such, people's rights were denied' (Pat O'Brien quoted in The Irish Times 5 March 2003). Clearly, while these groups are described as 'local campaigners' this descriptor does not come close to defining the networked nature of their campaign.

Networking on environmental issues has become faster and more immediate due to the 'network society'. Environmentalism, in the era of globalisation, supports and stimulates direct horizontal contacts between campaigners through the use of cyberpolitics and cybermedia. Evidence on the ground testified to Carnoy and Castell's argument that:

knowledge formation and power over knowledge in the global economy is moving out of control of the nation state, because innovation is globalised, because discourse on knowledge is outside the state's control, and because information is much more accessible than it was before thanks to technology and communications (2001: 11).

In speaking to social actors in our all-Ireland study of waste management it emerged that they thought that a key player was the waste multi-national company. It was apparent that there was considerable worry about the influence of commercial interests, specifically waste companies coming into the globalised waste market. In both jurisdictions the key worry from the environmentalists and local community activists was the role of 'big business', that is incineration companies involved in the implementation of the plan. They argued that there had been aggressive attempts by incinerator companies to lobby the government (Fagan and O'Hearn et al. 2001: 17) and to lead strategy. As the Northern environmental scientist put it 'the incineration industry, it is a bit of a dying industry and so they are looking for new avenues, they are looking for new places to go to build them, so they're looking to Eastern Europe and Ireland' (Fagan and O'Hearn et al. 2001: 16). This concurs with $O$ 'Brien's interpretation of the waste industry where he argues:

This is a market whose rational economic actors are begging, cajoling, threatening and coercing the states of Europe to intervene politically into the circulation of wastes precisely because the 'spontaneous' emergence of markets does not generate the values they want out of the rubbish heap (O'Brien 1999a: 292).

The environmentalists interviewed, North and South, felt that while the United States and Japan were trying to move away from incineration, Europe was lagging 
behind because there were 'vested interests' to be protected. The incineration companies were 'well known' as multinationals, but they would 'set up subsidiary companies' in Ireland. The environmentalists were paralleling the previous problem in the nation states of local authorities acquiring and mismanaging landfill sites the so-called 'planning' of 'dumping'- with the newer response of building incinerators. 'Okay so we can't dump everything anymore, so lets just burn it' was the rather cynical analysis of the situation presented by the Southern environmentalist (Fagan and O'Hearn et al. 2001: 16). By and large they believed that in both cases the government was 'being wooed by or was wooing' large international companies and taking little responsibility for negative impacts on localised communities.

The transnational linkages that inform national social movements and statebased issue actors demonstrates that subjects and spaces are formed in the interstices of complex political spaces that transcend national boundaries and state institutions (see Cohen and Rai 2000). The negative view of incineration held by local communities, environmental campaigners and the environmental scientists was one informed by global flows of knowledge, political and technological, through mobile campaigners and cyberpolitics. The Southern government had turned to the 'experts', the engineers for a technological fix to the waste issue. An assumption was that they were the technocrats who held the key to the embedded knowledge and information of waste management. The surprising nature of the local action's response was that it managed to link up, with a push of a button on the keyboard, to the cyberpolitics of international protest against waste. This is to say that there was a time-space intensification that aided the 'local' response to a surprising extent. The local action response was networked to a virtual community that could serve to disembed that 'professional' technological waste information and democratise it beyond the 'professional' discourse. The problematisation of waste management strategy achieved by the 'local' campaigners then has to be taken as a positive effect of networked governance in a fast globalising Ireland. Far from being simply about NIMBYism (Not in My Back Yardism) they use a discourse of responsibility, of environmentalism, and of political rights while at the same time they develop a multi-scalar political agency.

Most interesting then, over and above the fact that the new electronic media made possible a new kind of environmentalist, networked, flexible, media-orientated action, is the interplay, in the Irish situation, between the politics of cyberspace and the politics of place. It is precisely the dynamic interplay of these politics that makes them potentially most effective. As Escobar describes it, a cyberpolitics can be effective if it fulfils two conditions: awareness of the dominant worlds (in this case the world of consumerism) and an ongoing tacking back and forth between cyberpolitics and political activism in the place where the activist resides (1999: 32).

Lest we get over-enthusiastic here, let me clarify. In terms of the networks and the transformation theme running through this article, the democratisation of knowledge, which occurred through the electronic networking, facilitated a degree of social transformation. I would however strike a note of caution though 
against any 'Zapatista' interpretation of these 'glocal' networked campaigns around waste management issues (see www.eco.utexas.edu/Homepages/Faculty/ Cleaver/zapsincyber.html). Access to international best practice and campaigning resources is not the same as a new mode of revolution on a terrain as yet not colonised by capital as some see the Internet. There is, however, a small but growing body of evidence that electronic networks can be used to foster collective action. I am not referring here to electronic communication within an already existing transnational network of women, workers and environmentalists. Rather, I refer to these place-bound communities that Castells and others seem to see as somehow static and lost in a whirlwind of globalisation. Thus Christopher Mele (1999) reports on the use of the Internet to build effective collective action in a low-income public housing development in North Carolina. Mele refers to how 'the flexibility of the Internet proved useful in developing a surrogate electronic community and network and breaking down the isolation of Jervay and its residents' (Mele 1999: 305). Something similar can be seen in the Irish anti-incineration campaigns that needs to be further researched, but there is some preliminary evidence that global forces and global connections, in the case of opposition to waste plans, may have inspired 'social movements to seize control over their immediate but also their more distant worlds, challenging the mythology of an inexorable, runaway world' (Burawoy 2000: 29).

\section{Researching Waste}

We can contrast the politics of the sociological approach taken in our study with the politics of a report on waste management emerging in the same year from Forfás (the National Policy and Advisory Board for Enterprise, Trade, Science, Technology and Innovation set up to advise the Minister for Enterprise, Trade and Employment on matters relating to the development of industry in the state). Key Waste Management Issues in Ireland 2001 (The Republic of Ireland) is the outcome of a Forfás taskforce set up to tackle the issue of waste management. This sets waste management clearly in the context of industrial development where waste facilities are 'a factor towards the end' of maintaining competitiveness in the State's industrial policy (Harney 2001 in Forfás). The report according to the Tánaiste is 'timely and welcome as a reasoned contribution to the current debate' (my italics) (Harney 2001). It does not take a sociologist to point out that waste management is a contested terrain in Ireland today - it is quite unavoidable if you read the paper or listen to the news - but it appears that it does take a sociologist to point out that waste is a product of the social relations of global consumerism.

Throughout the past two years the national papers occasionally and the local newspapers constantly, have covered the confrontations that developed as a result of attempts to implement waste management regional plans. In fact my own interest developed when, having opted for a 'country life', the local newspaper 'The Meath Chronicle' consistently drew attention to the extent of the 'locals" response 
to proposed plans for incinerators. "Locals" response in this case appeared to me to be exceedingly more than 'local'. They seemed to be tuned in to global social movements discourse on the environment, and deeply embedded in, and sometimes represented by, globally networked expert environmental advice. The politics of the local regional plans for waste management appeared as a new 'glocal' politics, grounded in regions geographically distant from the core of Europe, but yet relating closely to transnational political processes. In the Republic, given that the terrain was not just contested but had become a 'burning issue', as one politician put it to us, even to write on the issue was inevitably the source of much contestation.

Our approach was to talk to representatives from all interested parties, enter into debate with them and report on what each saw as the key issues, the nature of the 'crisis', the drivers of waste plans and 'the way forward'. All parties initially welcomed this, but towards the end some of the institutional players became anxious that the findings might be escaping the parameters of what they considered to be the debate on waste management. In contrast, a national environmentalist meeting was interrupted by the Chair to 'thank the people who did this study' and said that it had given them 'great heart'! Of course this contestation of our findings and report is not surprising given the fraught terrain that waste management in Ireland is today.

My intention had been to enter into the contested terrain of waste in the island of Ireland in order to understand and faithfully record the viewpoints of the contesting parties, to analyse them from a social science perspective, focusing on its social construction, and to address the issue of governance with waste being conceived as an embodiment of social relations of consumerism. The research bargain was more fraught than usual, but precisely because research processes are embodied in social relations, a reflexive, interpretative and critical sociological analysis of 'glocalised' social processes has never been more necessary in my view.

\section{Notes}

1. Apart from a review of legislation and policy documents the research consisted of semistructured interviews with 'key players', or constituencies, followed by focus groups discussing the preliminary findings carried out in 2000 (significant given how rapidly the waste debate and policy is changing). The key players we interviewed North and South came from the following constituencies: Department of the Environment/Environmental Protection Agency; environmental scientists; environmental activists; environmentally minded politicians; environmental engineers and industrialists. We then held focus group discussions North and South with community groups that had been involved in waste and recycling campaigns and initiatives.

\section{References}

Becker, E. and T. Jahn (eds) 1999 Sustainability and the Social Sciences. London: Zed Books.

Burawoy, M. 2000 'Introduction. Reaching for the Global,' pp.1-40 in M. Burawoy, J.A. Blum, S. George, Z. Gille, T. Gowan, L. Haney. M. Klawiter, S. H. Lopez, S. Ó Riain 
and M. Thayer 2000 Global Ethnography: Forces, Connections, and Imaginations in A Postmodern World. California: University of California Press.

Carnoy M. and M. Castells 2001 'Globalisation , the knowledge society and the network state', Global Nenvorks 1(1): 1-19.

Castells, M. 2000 'Globalisation and identity in the network society', Prometheus 4: 109-23.

Cerny, P. 2000 'Structuring the political arena: public goods, states and governance in a globalizing world,' pp.21-35 in R. Palan (ed.) Global Political Economy: Contemporary Themes. London: Routledge.

Cohen, R and S. Rai (eds) 2000 Global Social Movements. London: Athlone Press.

Dempsey, Noel, TD 1998 Speech by Minister for the Environment at the launch of Waste Management: changing our ways, Customs House.

Dirlik, A. 1999 'Place-based imagination: globalism and the politics of place', Review xxii(2): 151-87.

Environmental Protection Agency 2002 Environment in Focus, 2002: Key Environmental Indicators for Ireland.

Escobar, A. 1999 'Gender, place and networks: a political ecology of cyberculture,' pp. 31-55 in W. Harcourt (ed.) New Cultures in Cyberspace. London: Zed Books.

European Environment Agency 1999 Environment in the European Union at the Turn of the Century. Luxemburg: EC Publications.

European Environment Agency 2002 Environmental Signals. Luxembourg: EC Publications. Fagan, H., D. O'Hearn, G. Mc Cann and M. Murray 2001 Waste Management Strategy: A Cross Border Perspective. Maynooth: National Institute for Regional and Spatial Analysis.

Forfás 2001 Key Waste Management Issues in Ireland.

Greenpeace 1993 The International Trade in Toxic Wastes: An International Inventory. Washington: Greenpeace International.

Harney, M. 2001 'Foreword by An Tánaiste and Minister for Enterprise, Trade and Employment,' in Forfás Key Waste management Issues in Ireland.

Held, D., A. Mc Grew, D. Goldblatt and J. Perraton 1999 Global Transformations: Politics, Economics and Culture. Cambridge: Polity.

Marston, S. 2000 'The social construction of scale', Progress in Human Geography 24: 219-242.

Massey, D. 1992 'Politics and space-time', New Left Review 196: 65-48.

Massey, D. 2000 'The geography of power', Red Pepper, July Issue.

Mele, C. 1999 'Cyberspace and disadvantaged communities: the Internet as a tool for collective action', pp.290-310 in M. Smith and P. Kollock (eds) Communities in Cyberspace. London: Routledge.

Murray, R. 1999 Creating Wealth from Waste. London: Demos.

O'Brien, M. 1999a 'Rubbish values: reflections on the political economy of waste', Science as Culture, 8(3): 269-95.

O'Brien, M 1999b'Rubbish-power: towards a sociology of the rubbish society, pp. 262-277 in J. Hearn and S. Roseneil (eds) Consuming Cultures: Power and Resistance. London: Macmillan.

Quinlivan, A. 2002 'European standards and waste management in Ireland: examining the local implementation deficit' Administration 50(2): 67-79.

Rathje, W. and C. Murphy 2001 Rubbish! The Archaeology of Garbage. Tucson: The University of Arizona Press.

Spaargaren, G., G. Moll and F. Buttel (eds) 2000 Environment and Global Modernity. London: Sage. 
Stoker, G. 1998 'Govemance as theory: five propositions' Journal of International Social Science, 155 (March): 18-32.

Strasser, S. 1999 Waste and Want: A Social History of Trash. New York: Metropolitan Books.

Urry, J. 1999 'Global Citizenship and the Environment: An ESRC funded research project' http://www.comp.lancs.ac.uk/sociology/jures.html.

Yearley, S 1995 'Dirty connections: transnational pollution,' pp. 143-183 in J. Allen and C. Hamnett (eds) A Shrinking World? Oxford: Open University Press. 
Copyright of Irish Journal of Sociology is the property of Irish Journal of Sociology and its content may not be copied or emailed to multiple sites or posted to a listserv without the copyright holder's express written permission. However, users may print, download, or email articles for individual use. 